\title{
Potensi Aktivitas Bakteriosin Lactobacillus gasseri Terhadap Pertumbuhan Salmonella typhi
}

\author{
Muhammad Rayhan Firdaus ${ }^{1}$, Andani Eka Putra ${ }^{2}$, Abdiana $^{3}$ \\ ${ }^{1}$ Program Studi Pendidikan Dokter Fakultas Kedokteran Universitas Andalas, Padang \\ ${ }^{2}$ Bagian Mikrobiologi Fakultas Kedokteran Universitas Andalas, Padang \\ ${ }^{3}$ Bagian IImu Kesehatan Masyarakat Fakultas Kedokteran Universitas Andalas, Padang
}

\author{
A B S T R A C T
}

\begin{abstract}
Latar belakang. Lactobacillus gasseri merupakan jenis bakteri asam laktat (BAL) yang dapat menghasilkan bakteriosin sebagai suatu senyawa antibakteri.

Objektif. untuk mengetahui potensi aktivitas bakteriosin Lactobacillus gasseri terhadap pertumbuhan Salmonella typhi dengan menilai Kadar Hambat Minimal (KHM) dan Kadar Bunuh Minimal (KBM).
\end{abstract}

Metode. Penelitian ini dilakukan dengan teknik dilusi dan menggunakan desain Rancangan Acak Lengkap. Konsentrasi bakteriosin Lactobacillus gasseri dibagi dalam berbagai kelompok konsentrasi yaitu 100\%, 80\%, 60\%, 40\%, 20\%, 10\% dan $0 \%$ (kontrol) dengan empat kali pengulangan. Nilai KHM dan KBM ditentukan dengan menghitung jumlah koloni bakteri yang tumbuh dari masing-masing konsentrasi. Hasil penelitian dianalisis secara statistik dengan uji One-way ANOVA dan PostHoc LSD.

Hasil. Hasil penelitian menunjukkan bahwa bakteriosin Lactobacillus gasseri dapat menghambat pertumbuhan Salmonella typhi namun tidak ditemukan nilai KHM dan KBM. Dengan perhitungan statistik ditemukan perbedaan yang bermakna pada konsentrasi $100 \%, 80 \%, 60 \%, 40 \%$ dan $20 \%$ terhadap kontrol.

Simpulan. bakteriosin Lactobacillus gasseri memiliki efek bakteriostatik terhadap pertumbuhan Salmonella typhi tetapi tidak memiliki efek bakterisidal. Kemampuan daya hambat bakteriosin Lactobacillus gasseri terhadap pertumbuhan Salmonella typhi dipengaruhi oleh konsentrasi bakteriosinya.

Kata kunci: antibakteri, bakteriosin, lactobacillus gasseri, salmonella typhi

Background. Lactobacillus gasseri is a type of lactic acid bacteria (BAL) that can produce bacteriocin as an antibacterial compound.

Objective. To determine the potential activity of Lactobacillus gasseri bacteriocin on the growth of Salmonella typhi by assessing the Minimum Inhibitory Level (MIC) and the
Minimum Bactericidal Concentration (MBC).

Method. This research was conducted with the dilution technique and using a completely randomized design. The concentration of Lactobacillus gasseri bacteriocin was divided into various concentration groups namely 100\%, 80\%, 60\%, $40 \%, 20 \%, 10 \%$ and $0 \%$ (control) with four repetitions. The MIC and $M B C$ values were determined by counting the number of bacterial colonies that grew from each concentration. The results of the study were statistically analyzed with the Oneway ANOVA and Post-Hoc LSD tests.

Results. The results showed that the bacteriocin Lactobacillus gasseri could inhibit the growth of Salmonella typhi but found no MIC and MBC values. Statistical calculations found significant differences in the concentration of $100 \%, 80 \%$, $60 \%, 40 \%$ and $20 \%$ of the controls.

Conclusion. Bacteriocin Lactobacillus gasseri has a bacteriostatic effect on the growth of Salmonella typhi but has no bactericidal effect. The ability of Lactobacillus gasseri bacteriocin to inhibit the growth of Salmonella typhi is influenced by the concentration of bacteriocytes.

Keyword: antibacterial, bacteriocin, lactobacillus gasseri, salmonella typhi

\section{Apa yang sudah diketahui tentang topik ini?}

Bakteriosin L. gasseri mempunyai efek bakteriostatik terhadap S. typhi

\section{Apa yang ditambahkan pada studi ini?}

Menilai Kadar Hambat Minimal (KHM) dan Kadar Bunuh Minimal (KBM) dari Bakteriosin L. gasseri terhadap $S$. typhi.

\section{CORRESPONDING AUTHOR}

Phone: +6285374396797

E-mail: mrayhanfirdaus.31@gmail.com 


\section{Pendahuluan}

Tifoid merupakan penyakit endemik di Indonesia yang disebabkan oleh bakteri Salmonella typhi. Penyakit ini merupakan penyakit yang mudah menular dan dapat menyerang banyak orang melalui rute fekal-oral. Penyakit ini biasanya menyerang usus, menyebabkan luka pada saluran pencernaan dan bahkan terjadi kebocoran usus. Penyakit ini sangat dipengaruhi oleh kualitas kebersihan dari masing-masing individu serta kualitas sanitasi lingkungan yang sangat rendah. ${ }^{1}$

Penyakit tifoid mengakibatkan 11-20 juta kasus per tahun dengan $128.000-161.000$ kematian tiap tahunnya di seluruh dunia (WHO 2018). Demam tifoid masih umum terjadi di negara-negara berkembang, terbukti dengan insiden tertinggi tifoid yang ditemukan di Asia Selatan, Asia Tenggara, dan Afrika Selatan dengan lebih dari 100 kasus per 100.000 populasi setiap tahunnya. ${ }^{2}$

Dewasa ini penyakit tifoid mempunyai permasalahan yang semakin kompleks, diantaranya terdapat gejala klinik yang bervariasi dengan komplikasi yang berbahaya, adanya komorbid atau koinfeksi dengan penyakit lain, angka peningkatan resistensi terhadap obat-obat yang dipakai serta peningkatan kasus karier atau relaps. Hal ini menyulitkan upaya pengobatan dan pencegahan dari penyakit ini sehingga tifoid berada di urutan nomor 3 pada 10 pola penyakit terbanyak pasien rawat inap di rumah sakit di Indonesia tahun 2010, dengan total kasus 41.081 jiwa, dimana 274 kasus meninggal dan Case Fatality Rate (CFR\%) 0,67 \%. ${ }^{3}$

Bakteri Salmonella thypi sudah banyak mengalami resistensi terhadap beberapa antibiotik. WHO melaporkan resistensi di Meksiko dan Vietnam terjadi sejak awal 1970-an. Laporan pertama terjadi pada tahun 1974 yang menyatakan bahwa Salmonella thypi mengalami resistensi terhadap kloramfenikol, lalu diikuti dengan laporan resistensi Salmonella thypi terhadap ampisilin dan trimetoprim sulfametoksazol atau yang dikenal dengan Multiple Drug Resistance (MDR) Salmonella thypi. ${ }^{4}$

Oleh karena itu, mengendalikan infeksi melalui pendekatan non-antibiotik sangatlah dibutuhkan.
Potensi penggunaan Lactobacillus untuk mengendalikan demam tifoid merupakan pendekatan yang menjanjikan, karena dapat mengerahkan tindakan perlindungan melalui berbagai mekanisme dan terdapat aktivitas antibakteri Lactobacilli terhadap bakteri patogen (Escherichia coli, Salmonella typhimurium, Vibrio cholerae). ${ }^{5}$

Beberapa penelitian eksperimental in vitro dan in vivo serta uji klinis telah menunjukkan peran protektif dari strain Lactobacillus dalam menangkal berbagai infeksi usus, seperti diare terkait antibiotik, gastroenteritis Helicobacter pylori, dan infeksi urogenital. ${ }^{6}$ Serta peran dari Lactobacillus plantarum dapat melindungi terhadap infeksi Salmonella typhi. ${ }^{5}$

Lactobacillus merupakan salah satu dari 20 genus yang termasuk dalam kategori BAL (Bakteri Asam Laktat). BAL memproduksi senyawa antimikroba (penghambat bakteri lain) berupa bakteriosin, hidrogen peroksida, asam lemah, reuterin dan diasetil. Kelompok senyawa ini mempunyai fungsi masing-masing yang berguna dalam mengurangi jumlah bakteri patogen di dalam tubuh manusia dan hewan. ${ }^{7}$

Bakteri asam laktat, terutama spesies yang termasuk dalam genus Lactobacillus, seperti $L$. acidophilus, L. rhamnosus, L. gasseri, L. fermentum, dan L. plantarum bertindak sebagai probiotik penting karena sifat spesifik-regangannya yang bermanfaat bagi kesehatan. ${ }^{8}$ Untuk berfungsi sebagai probiotik, strain bakteri harus memenuhi persyaratan tertentu termasuk resistensi terhadap asam tinggi dan konsentrasi empedu. Sifat fungsional lainnya untuk mengkarakterisasi probiotik adalah kemampuan bakteri memperbaiki sel epitel usus (adhesi, agregasi dan koagregasi), produksi senyawa antimikroba, dan kemampuan untuk memodulasi respon imun. ${ }^{9}$

Strain Lactobacillus ditemukan secara alami di usus manusia, dan untuk alasan ini, strain tersebut lebih disukai dikembangkan untuk penggunaan komersial sebagai probiotik. Beberapa peneliti melaporkan bahwa bakteri yang diisolasi terutama dari kotoran bayi atau manusia lanjut usia memiliki sifat probiotik potensial. ${ }^{10}$

Secara umum dapat dikatakan bahwa bakteri Lactobacillus gasseri menunjukkan kemampuan 
antimikroba terhadap bakteri patogen dengan tiga metode, yakni Punctuation method (Agar spots), Well Plates (Well diffusion agar) dan Disk method (Disk diffusion agar). Dengan ke tiga metode yang diteliti mampu menghambat pertumbuhan strain patogen Salmonella enterica typhi sehingga hal ini dapat diteliti dengan menentukan Kadar Hambat Minimal (KHM) dan Kadar Bunuh Minimal (KBM) yang dihasilkan dari bakteri Lactobacillus gasseri terhadap Salmonella typhi. ini menunjukkan bahwa peran positif bakteri dalam kesehatan manusia dan penggunaan Lactobacillus gasseri untuk pencegahan dan pengobatan infeksi saluran pencernaan dapat diterima dan menjadi pengobatan yang menjanjikan. ${ }^{11}$

\section{Metode}

Jenis penelitian ini adalah true-experimental, dengan desain eksperimen yang digunakan dalam penelitian ini adalah Rancangan Acak Lengkap (RAL). Variabel independennya adalah Bakteriosin yang dihasilkan oleh bakteri Lactobacillus gasseri dan variabel dependennya adalah Daya hambat terhadap pertumbuhan bakteri Salmonella thypi, terdiri dari KHM (Kadar Hambat Minimal) dan KBM (Kadar Bunuh Minimal).

Populasi dan sampel penelitian ini adalah bakteri Salmonella thypi yang diperoleh dari koleksi Laboratorium Mikrobiologi Fakultas Kedokteran Universitas Andalas. Setiap sampel diulangi sebanyak empat kali sesuai dengan perhitungan menggunakan rumus Federer. Bakteri Salmonella typhi akan dikenai penghambatan pertumbuhan dengan berbagai kelompok konsentrasi dari Bakteriosin Lactobacillus gasseri, yaitu 100\%; 80\%; 60\%; 40\%; 20\%; 10\% dan 0\% sebagai kontrol.

Bahan yang digunakan dalam penelitian ini adalah sebagai berikut: Isolat bakteri Lactobacillus gasseri dari feses manusia koleksi milik Dr. dr. Andani Eka Putra, M.Sc, Media De Mann Ragosa Sharpe (MRS) Broth, Media De Mann Ragosa Sharpe (MRS) Padat, Biakan Salmonella thypi, Media nutrient broth, Muller Hilton Agar (MHA) II, Standard Mc. Farland 0.5, NaOH 2 N, Aquades dan $\mathrm{NaCl}$ 0,9\%.

Daya hambat bakteriosin Lactobacillus gasseri ditentukan dengan metode dilusi secara invitro. Bakteriosin Lactobacillus gasseri dibagi menjadi beberapa konsentrasi dengan cara pengenceran serial, yaitu: $100 \%, 80 \%, 60 \%, 40 \%, 20 \%, 10 \%$ dan $0 \%$ sebagai kontrol. Bakteriosin Lactobacillus gasseri dimasukkan kedalam setiap tabung reaksi berisi nutrient broth yang telah ditentukan volumenya dan $0,1 \mathrm{ml}$ suspensi bakteri. Masingmasing konsentrasi dibuat empat kali pengulangan, setiap kombinasi perlakuan berjumlah 2,1 ml untuk 100\% campurannya.

Dalam menentukan ada atau tidaknya pertumbuhan bakteri Salmonella thypi dapat dilakukan dengan uji TPC (Total Plat Count) pada media PCA (Plat Count Agar) menggunakan teknik cawan sebar (spread plate), yakni dengan cara masing-masing tabung diencerkan sampai pada konsentrasi $10^{-7} \mathrm{CFU} / \mathrm{ml}$ dan divortex. Setelah itu setiap konsentrasi diambil $0,1 \mathrm{ml}$ diteteskan kedalam cawan petri yang sudah berisi agar Muller Hilton II dan sampel diratakan. Kemudian cawan petri diinkubasi pada suhu $37^{\circ} \mathrm{C}$ selama 24 jam.

KHM dan KBM dapat ditentukan setelah dilakukan perhitungan terhadap jumlah koloni bakteri Salmonella typhi yang masih dapat tumbuh dengan ketentuan bahwa pertumbuhan koloni setiap konsentrasi yang sudah dikultur lebih sedikit daripada konsentrasi 0\% (kontrol). Konsentrasi terendah yang dapat menghambat 90\% pertumbuhan koloni bakteri Salmonella typhi setelah inkubasi 24 jam ditetapkan sebagai KHM, sedangkan konsentrasi terendah yang dapat membunuh 99,9\% pertumbuhan koloni bakteri Salmonella typhi setelah inkubasi 24 jam ditetapkan sebagai KBM.

Data hasil pengamatan dicatat, ditabulasi dan dianalisis secara statistik dengan taraf signifikansi $0,05(\mathrm{p}=0,05)$. Analisis data terdiri dari uji normalitas data (Shapiro-Wilk), uji homogenitas varian dan uji One-Way ANOVA. Bila didapatkan hasil bermakna $(\mathrm{p}<0,05)$, dilanjutkan dengan uji post-hoc LSD (Least Significan Difference).

\section{Hasil}

Hasil penelitian potensi aktivitas bakteriosin Lactobacillus gasseri dalam berbagai konsentrasi terhadap pertumbuhan Salmonella typhi dapat dilihat pada tabel berikut. 
Tabel 1. Pengaruh Aktivitas Bakteriosin Lactobacillus Gasseri Dengan Berbagai Konsentrasi Terhadap Pertumbuhan Salmonella Typhi

\begin{tabular}{|c|c|c|c|c|c|c|}
\hline \multirow[t]{2}{*}{ Kelompok } & \multicolumn{4}{|c|}{$\begin{array}{c}\text { Jumlah Koloni S. typhi } \\
\text { (4x pengulangan) }\end{array}$} & \multirow{2}{*}{$\begin{array}{c}\text { Rerata } \\
\left(10^{6}\right. \\
\text { CFU/ml })\end{array}$} & \multirow[t]{2}{*}{$\begin{array}{c}\log 10 \\
(\mathrm{CFU} / \mathrm{ml})\end{array}$} \\
\hline & $\begin{array}{c}1\left(10^{6}\right. \\
\mathrm{CFU} / \mathrm{ml})\end{array}$ & $\begin{array}{c}2\left(10^{6}\right. \\
\mathrm{CFU} / \mathrm{ml})\end{array}$ & $\begin{array}{c}3\left(10^{6}\right. \\
\mathrm{CFU} / \mathrm{ml})\end{array}$ & $\begin{array}{c}4\left(10^{6}\right. \\
\mathrm{CFU} / \mathrm{ml})\end{array}$ & & \\
\hline$K(0 \%)$ & 140 & 90 & 115 & 82 & 106,75 & 8,03 \\
\hline Pl (10\%) & 70 & 85 & 89 & 81 & 81,25 & 7,91 \\
\hline$P 2(20 \%)$ & 35 & 36 & 40 & 36 & 36,75 & 7,57 \\
\hline P3 (40\%) & 26 & 34 & 28 & 24 & 28,00 & 7,45 \\
\hline P4 (60\%) & 20 & 25 & 20 & 19 & 21,00 & 7,32 \\
\hline P5 (80\%) & 19 & 23 & 18 & 19 & 19,75 & 7,30 \\
\hline P6 (100\%) & 10 & 22 & 17 & 17 & 16,50 & 7,22 \\
\hline
\end{tabular}

Dari tabel di atas $(\mathrm{K}=$ Kelompok Kontrol 0\%, $\mathrm{P}_{1-6}=$ Kelompok Percobaan 0\%, 20\%, 40\%, 60\%, $80 \%$ dan $100 \%$ ), didapatkan nilai rerata dari koloni Salmonella typhi yang tumbuh mengalami penurunan koloni dengan bertambahnya jumlah konsentrasi jika dibandingan dengan kontrol.

\section{Kadar Hambat Minimal dan Kadar Bunuh Minimal dari potensi aktivitas bakteriosin $\begin{array}{ll}\text { Lactobacillus gasseri } & \text { terhadap } \\ \text { pertumbuhan Salmonella typhi }\end{array}$}

Tabel 2. Jumlah Penurunan Populasi Bakteri Indikator pada Berbagai Konsentrasi Lactobacillus gasseri

\begin{tabular}{|c|c|c|c|c|c|c|}
\hline $\begin{array}{c}\text { Bakteri } \\
\text { Indikator }\end{array}$ & Kelompok & $\begin{array}{c}\text { Jumlah } \\
\text { Populasi } \\
\text { Bakteri } \\
\text { (CFU/ml) }\end{array}$ & $\begin{array}{c}\text { Penurunan } \\
\text { Jumlah } \\
\text { Populasi } \\
\text { Bakteri } \\
\text { (CFU/ml) }\end{array}$ & $\begin{array}{c}\text { Persentase } \\
\text { Penurunan } \\
\text { Jumlah } \\
\text { Bakteri } \\
\text { Indikator } \\
(\%) \\
\end{array}$ & $\begin{array}{c}\text { Kadar } \\
\text { Hambat } \\
\text { Minimal } \\
(\mathrm{KHM})\end{array}$ & $\begin{array}{c}\text { Kadar } \\
\text { Bunuh } \\
\text { Minimal } \\
\text { (KBM) }\end{array}$ \\
\hline \multirow{7}{*}{$\begin{array}{c}\text { Salmonella } \\
\text { typhi }\end{array}$} & $\mathrm{K}(0 \%)$ & 106,75 & - & - & - & - \\
\hline & P1 (10\%) & 81,25 & 25,50 & 23,9 & Tidak ada & Tidak ada \\
\hline & P2 (20\%) & 36,75 & 70,00 & 65,6 & Tidak ada & Tidak ada \\
\hline & P3 (40\%) & 28,00 & 78,75 & 73,8 & Tidak ada & Tidak ada \\
\hline & P4 (60\%) & 21,00 & 85,75 & 80,3 & Tidak ada & Tidak ada \\
\hline & P5 $(80 \%)$ & 19,75 & 87,00 & 81,5 & Tidak ada & Tidak ada \\
\hline & P6 (100\%) & 16,50 & 90,25 & 84,5 & Tidak ada & Tidak ada \\
\hline
\end{tabular}

Dari tabel di atas $(\mathrm{K}=$ Kelompok Kontrol 0\%, $\mathrm{P}_{1-6}=$ Kelompok Percobaan 0\%, 20\%, 40\%, 60\%, $80 \%$ dan $100 \%$ ), dapat dilihat Kadar hambat minimal (KHM) dalam penelitian ini tidak ditemukan dikarenakan tidak adanya perlakuan yang menunjukkan penurunan jumlah koloni Salmonella typhi sebanyak $\geq 90 \%$ dari kontrol.

Sedangkan kadar bunuh minimal (KBM) dalam penelitian ini juga tidak dapat temukan dikarenakan semua hasil kultur menunjukkan adanya pertumbuhan Salmonella typhi ditandai dengan adanya kekeruhan pada hasil inkubasi selama 24 jam.

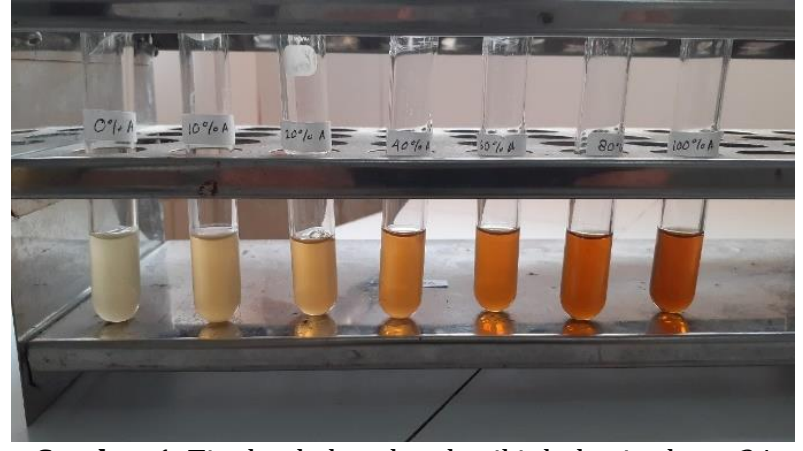

Gambar 1. Tingkat kekeruhan hasil inkubasi selama 24 jam

\section{Analisis statistika penelitian}

Berdasarkan uji statistik normalitas data dengan menggunakan Shapiro-wilk masingmasing konsentrasi didapatkan nilai signifikansi $p>0,05$ sehingga data dianggap terdistribusi normal. Uji homogenitas didapatkan nilai signifikansi $0,105 \quad(p>0,05) \quad$ sehingga data menunjukkan tidak terdapat perbedaan varians pada beberapa populasi. Berdasarkan hasil uji statistik di atas, maka analisis dapat dilanjutkan dengan uji statistik One Way ANOVA dan uji Post Hoc LSD.

Pada uji One Way ANOVA didapatkan nilai signifikansi $0,000 \quad(p<0,05)$. Dan dilanjutkan dengan uji Post Hoc LSD $(p<0,05)$ maka didapatkan perbedaan yang bermakna pada konsentrasi Percobaan $\left(\mathrm{P}_{1-6}\right) 100 \%, 80 \%, 60 \%$, $40 \%$ dan $20 \%$ terhadap kontrol (K) $0 \%$.

Tabel 3. Nilai Signifikansi (p) pada uji Post Hoc LSD antara masing-masing konsentrasi

\begin{tabular}{|c|c|c|c|c|c|c|c|}
\hline & $\begin{array}{c}\mathrm{K} \\
(0 \%)\end{array}$ & $\begin{array}{c}\text { P1 } \\
(10 \%)\end{array}$ & $\begin{array}{c}\text { P2 } \\
(20 \%)\end{array}$ & $\begin{array}{c}\text { P3 } \\
(40 \%)\end{array}$ & $\begin{array}{c}\text { P4 } \\
(60 \%)\end{array}$ & $\begin{array}{c}\text { P5 } \\
(\mathbf{8 0} \%)\end{array}$ & $\begin{array}{c}\text { P6 } \\
(100 \%)\end{array}$ \\
\hline $\begin{array}{c}\mathrm{K} \\
(0 \%)\end{array}$ & & 0,061 & 0,000 & 0,000 & 0,000 & 0,000 & 0,000 \\
\hline $\begin{array}{c}\text { Pl } \\
(10 \%)\end{array}$ & 0,061 & & 0,000 & 0,000 & 0,000 & 0,000 & 0,000 \\
\hline $\begin{array}{c}\text { P2 } \\
(20 \%)\end{array}$ & 0,000 & 0,000 & & 0,042 & 0,000 & 0,000 & 0,000 \\
\hline $\begin{array}{c}\text { P3 } \\
(40 \%)\end{array}$ & 0,000 & 0,000 & 0,042 & & 0,038 & 0,014 & 0,000 \\
\hline $\begin{array}{c}\text { P4 } \\
(60 \%)\end{array}$ & 0,000 & 0,000 & 0,000 & 0,038 & & 0,646 & 0,045 \\
\hline $\begin{array}{c}\text { P5 } \\
(80 \%)\end{array}$ & 0,000 & 0,000 & 0,000 & 0,014 & 0,646 & & 0,111 \\
\hline $\begin{array}{c}\text { P6 } \\
(100 \%)\end{array}$ & 0,000 & 0,000 & 0,000 & 0,000 & 0,045 & 0,111 & \\
\hline
\end{tabular}

\section{Pembahasan}

\section{Produksi Bakteriosin}

Bakteriosin merupakan peptida antimikroba hasil dari sintesis ribosom suatu bakteri yang aktif melawan bakteri lain baik secara bakteriostatik maupun bakterisidal. Bakteriosin diperoleh dengan cara mengkultur isolat Lactobacillus gasseri dalam media pertumbuhan MRS Broth 
selama 24-48 jam. Waktu inkubasi ini berperan penting dalam produksi bakteriosin. Produksi bakteriosin oleh Lactobacillus gasseri dimulai saat akhir fase eksponensial dan mencapai maksimal pada fase stasioner, ini menunjukkan bahwa bakteriosin merupakan metabolit yang primer. adapun faktor-faktor yang dapat menggangu produksi bakteriosin oleh Lactobacillus yakni: kondisi proses yang tidak sesuai $(\mathrm{pH}$, suhu, nutrisi), kehilangan sel spontan pada produksi bakteriosin, infeksi sel dan terdapatnya mikroorganisme kompetitif pada media. ${ }^{7}$

Hasil kultur kemudian disentrifus untuk memisahkan sel dengan filtratnya yang berisi metabolit dari Lactobacillus gasseri. Filtrat diperoleh dalam kondisi asam, hal ini menunjukkan bahwa filtrat mengandung asam organik seperti asam laktat dan asam asetat. dan untuk mencegah adanya efek antimikroba yang disebabkan oleh asam organik maka dilakukan penambahan $\mathrm{NaOH}$ hingga filtrat mencapai kondisi pada $\mathrm{pH} 7.12$

\section{Potensi aktivitas bakteriosin Lactobacillus gasseri terhadap pertumbuhan Salmonella typhi}

Pada penelitian ini bakteriosin Lactobacillus gasseri mampu menurunkan pertumbuhan Salmonella typhi. Penurunan pertumbuhan tersebut tampak dari jumlah koloni Salmonella typhi yang tumbuh pada masing-masing konsentrasi lebih kecil dibandingkan dengan konsentrasi $0 \%$ (kontrol). Pada penelitian ini konsentrasi bakteriosin Lactobacillus gasseri yang dapat menghambat pertumbuhan Salmonella typhi adalah konsentrasi 100\%, 80\%, 60\%, 40\%, 20\% dan $10 \%$. Hal ini juga didukung oleh penelitian yang menyatakan bahwa Lactobacillus menghasilkan zat penghambat bakteriosin yaitu senyawa protein yang dihasilkan oleh bakteri yang memiliki aktivitas bakteriostatik.

Penelitian ini dapat menjelaskan bahwa konsentrasi bakteriosin Lactobacillus gasseri $100 \%$ memiliki jumlah rata-rata koloni bakteri Salmonella typhi yang lebih rendah dibandingkan dengan konsentrasi 80\%,60\%,40\%, 20\%, 10\% dan $0 \%$. Dapat disimpulkan bahwa semakin meningkat konsentrasi bakteriosin Lactobacillus gasseri maka semakin menurun jumlah koloni bakteri Salmonella typhi, dan sebaliknya. Hal ini sesuai dengan penelitian yang dilakukan oleh Joko
Purnama (2017) yang pada penelitian tersebut menggunakan Lactobacillus plantarum sebagai antibakteri dari Salmonella typhi. Walaupun berbeda jenis Lactobacillus namun mekanisme dan kinerja dari bakteriosinnya sama-sama mampu menghambat pertumbuhan dari Salmonella typhi. ${ }^{13}$

\section{Kadar Bunuh Minimal (KBM) dan Kadar Hambat Minimal (KHM)}

KBM untuk bakteriosin Lactobacillus gasseri pada penelitian ini tidak dapat ditemukan karena pada penelitian ini menunjukkan semua konsentrasi yang dikultur memperlihatkan pertumbuhan koloni dari Salmonella typhi. Hal ini bertentangan dengan penelitian yang menjelaskan bahwa Lactobacillus termasuk dalam kategori BAL (Bakteri Asam Laktat). BAL memproduksi senyawa antimikroba (penghambat bakteri lain) berupa bakteriosin, hidrogen peroksida, asam lemah, reuterin dan diasetil. Kelompok senyawa ini mempunyai fungsi masing-masing yang berguna dalam mengurangi jumlah bakteri patogen di dalam tubuh manusia.6,7

Sedangkan untuk KHM dari bakteriosin Lactobacillus gasseri pada penelitian ini juga tidak dapat di temukan. Hal ini sesuai dengan teori minimal koloni bakteri patogen untuk menghitung KHM adalah $\geq 90 \%$. Namun pada penelitian ini tidak ada konsentrasi bakteriosin Lactobacillus gasseri yang mampu menghambat pertumbuhan bakteri Salmonella typhi lebih dari 90\%. Bisa disimpulkan bahwa bakteriosin Lactobacillus gasseri tidak memiliki efek bakterisidal, tetapi mempunyai efek bakteriostatik terhadap bakteri Salmonella typhi. Hal ini terlihat dari semua konsentrasi yang dikultur memperlihatkan adanya pertumbuhan bakteri Salmonella typhi, semakin tinggi konsentrasi maka semakin sedikit pertumbuhan bakteri Salmonella typhi. Hasil penelitian lain yang dilakukan oleh Barzavar dan Rahimifard juga menunjukkan efek bakteriostatik dari bakteriosin Lactobacillus gasseri terhadap pertumbuhan bakteri patogen. ${ }^{11}$

Dari uji statistik yang dilakukan, dapat di ambil kesimpulan bahwa konsentrasi $100 \%, 80 \%, 60 \%$, $40 \%$ dan $20 \%$ memiliki hasil yang bermakna terhadap kontrol (0\%). Hal tersebut dibuktikan dari uji Post Hoc LSD yang menunjukkan nilai 0,000 pada konsentrasi $100 \%, 80 \%, 60 \%, 40 \%$ dan $20 \%$ terhadap kontrol. 


\section{Mekanisme hambat pertumbuhan Salmonella typhi oleh bakteriosin Lactobacillus gasseri}

Salmonella typhi merupakan bakteri gram negatif. Bakteri gram negatif cenderung lebih mudah dihambat oleh senyawa yang dihasilkan oleh bakteri asam laktat (BAL) dibandingkan dengan bakteri gram positif. Bakteri gram negatif sensitif terhadap tingkat $\mathrm{pH}$ yang rendah dibandingkan bakteri gram positif. ${ }^{14}$

Bakteriosin adalah metabolit (ekstraseluler) berupa protein yang disintesis langsung di ribosom yang dapat menghambat bakteri Gram positif dan negatif. Cara kerja bakteriosin dalam melawan bakteri patogen dengan menyerang dinding sel atau membran sitoplasma melalui pembentukan pori pada membran sitoplasma sel patogen dan menerobos membran sel mengakibatkan peningkatan permeabilitas membran sitoplasma. 15

Lipid pada membran sitoplasma memiliki muatan negatif sehingga merupakan reseptor utama bagi bakteriosin dalam proses pembentukan pori. Adanya interaksi elektrostatik bakteriosin yang bermuatan positif bersifat hidrofobik dengan gugus fosfat bermuatan negatif pada membran sel target yang akan mengakibatkan terjadinya pengikatan bakteriosin dengan membran target dan ini merupakan tahap awal bakteriosin untuk menembus dinding sel.

Proses ini mengakibatkan terganggunya potensial membran berupa distabilitas membran sitoplasma sehingga sel menjadi tidak kuat. Ketidakstabilan membran bisa berdampak terjadinya pembentukan lubang atau pori pada membran sel bakteri patogen. Kebocoran ini menyebabkan penurunan $\mathrm{pH}$ seluler. Pengaruh dari kebocoran membran sitoplasma yang merupakan dampak bakteriosin sehingga mampu mengubah gradien potensial membran dan juga pelepasan molekul interseluler, serta masuknya substansi ekstraseluler. Hal tersebut dapat berpengaruh dalam menghambat pertumbuhan sel bakteri patogen dan mampu menyebabkan kematian sel bakteri yang sensitif terhadap bakteriosin. 16

\section{Simpulan}

Berdasarkan hasil penelitian ini didapatkan kesimpulan bahwa bakteriosin Lactobacillus gasseri memiliki efek bakteriostatik terhadap pertumbuhan Salmonella typhi tetapi tidak memiliki efek bakterisidal. Namun tidak didapatkan Kadar Hambat Minimal (KHM) dan Kadar Bunuh Minimal (KBM) dari penelitian ini.

\section{Ucapan Terima Kasih}

Terima kasih penulis sampaikan kepada semua pihak yang telah membantu penyelesaian penilitian ini terutama dari tim Laboratorium Mikrobiologi Fakultas Kedokteran Universitas Andalas.

\section{Daftar Pustaka}

1. Carroll KC, Hobden JA, Miller S, Morse SA. Jawetz, Melnick \& Adelberg's medical microbiology. 27th ed. New York: Mcgraw-Hill Education. 2016; 250-7.

2. WHO. Typhoid surveillance standards. 2018; 1-13. (Diakses 11 September 2019) Available from: https://www.who.int/immunization/monitoring_sur veillance/burden/vpd/WHO_SurveillanceVaccinePre ventable_21_Typhoid_R1.pdf?ua=1

3. Depkes RI. Profil kesehatan Indonesia 2010. In: Indonesia KKR; 2011.

4. Alam A. Pola resistensi Salmonella enterica serotipe typhi, Departemen Ilmu Kesehatan Anak RSHS, Tahun 2006-2010. Sari Pediatr. 2016;12(5):296.

5. Nelintong N, Isnaeni, Nasution N. Aktivitas antibakteri susu probiotik. J Farm dan Ilmu Kefarmasian Indones. 2015;2(1):25-30.

6. Reid G, Jass J, Sebulsky MT, Mccormick JK. Potential uses of probiotics in clinical practice. 2014;16(May):658-72.

7. Lahtinen S, Ouwehand AC, Salminen S, Wright A. Lactic Acid Bacteria - Microbiological and functional aspects. 4th ed. Florida: CRC Press; 2013. 1 p.

8. Giraffa G, Chanishvili N, Widyastuti Y. Importance of lactobacilli in food and feed biotechnology. Res Microbiol. 2010;161(6):480-7.

9. Zielińska D, Rzepkowska A, Radawska A, Zieliński K. In vitro screening of selected probiotic properties of Lactobacillus strains isolated from traditional fermented cabbage and cucumber. Curr Microbiol. 2015;70(2):183-94.

10. Kirtzalidou E, Pramateftaki P, Kotsou M, Kyriacou A. Screening for lactobacilli with probiotic properties in the infant gut microbiota. Anaerobe. 2011;17(6):440-3.

11. Barzavar M, Rahimifard N. Evaluation of the antimicrobial activity of lactobacillus gasseri as probiotic bacteria against salmonella enterica sero type entertidis. GMP Rev. 2015;16(4):56-64..

12. Gautam N, Sharma N. Bacteriocin: Safest approach to preserve food products. Indian J Microbiol. 2009;49(3):204-11.

13. Purnama J. Uji daya hambat filtrat Lactobacillus plantarum dari probiotik dadih terhadap pertumbuhan Salmonella thypi. J Kesehat Andalas. 2017.

14. Ray B, Bhunia A. Fundamental food microbiology. 5th ed. New York: CRC Press; 2013. 663 p.

15. Aslam M, Shahid M, Rehman FU, Naveed NH, Batool AI, Sharif S, et al. Purification and characterization of bacteriocin isolated from Streptococcus 
thermophilus. African J Microbiol Res.

2011;5(18):2642-8.

16. Usmiati S. Daging tahan simpan dengan bakteriosin. War Penelit dan Pengemb Pertan. 2012;34(2):12-4. 